\title{
Article \\ The Physical and Mechanical Properties of Autoclaved Aerated Concrete (AAC) with Recycled AAC as a Partial Replacement for Sand
}

\author{
Abdul Rahman Rafiza ${ }^{1, *}$, Ahmad Fazlizan ${ }^{1, * \mathbb{D}}$, Atthakorn Thongtha ${ }^{2} \mathbb{D}$, Nilofar Asim ${ }^{1}$ \\ and Md Saleh Noorashikin ${ }^{3}$
}

1 Solar Energy Research Institute, Universiti Kebangsaan Malaysia, Bangi 43600, Selangor, Malaysia; nilofarasim@ukm.edu.my

2 Department of Physics, Faculty of Science, Naresuan University, Phitsanulok 65000, Thailand; atthakornt@nu.ac.th

3 Research Centre for Sustainable Process Technology (CESPRO), Chemical Engineering Programme, Faculty of Engineering and Built Environment, Universiti Kebangsaan Malaysia, Bangi 43600, Selangor, Malaysia; noorashikin@ukm.edu.my

* Correspondence: p88891@siswa.ukm.edu.my (A.R.R.); a.fazlizan@ukm.edu.my (A.F.)

Citation: Rafiza, A.R.; Fazlizan, A.; Thongtha, A.; Asim, N.; Noorashikin, M.S. The Physical and Mechanical Properties of Autoclaved Aerated Concrete (AAC) with Recycled AAC as a Partial Replacement for Sand. Buildings 2022, 12, 60. https:// doi.org/10.3390/buildings12010060

Academic Editor: Marco

Di Ludovico

Received: 25 November 2021

Accepted: 5 January 2022

Published: 7 January 2022

Publisher's Note: MDPI stays neutral with regard to jurisdictional claims in published maps and institutional affiliations.

Copyright: (c) 2022 by the authors. Licensee MDPI, Basel, Switzerland. This article is an open access article distributed under the terms and conditions of the Creative Commons Attribution (CC BY) license (https:/ / creativecommons.org/licenses/by/ $4.0 /)$.

\begin{abstract}
The application of AAC has increased considerably in Malaysia since the 1990s. The usage of AAC has some advantages, but it also has negative environmental impacts since rejected concrete will become landfill. This study aimed to use AAC waste powder as a material that would partially replace the sand content to produce a new form of Autoclaved Aerated Concrete (AAC). The physical and mechanical properties of the newly developed AAC were investigated. This paper presents improved mechanical and physical properties of the new form of recycled AAC concrete. Besides these improvements, using recycled AAC could lower production costs. Furthermore, the usage of this recycled waste powder is both economically and environmentally advantageous. This study found that when recycled AAC was substituted for sand, AAC with a fine recycled powder content of $30 \%$ had a compressive strength that was around $16 \%$ higher than conventional AAC and between $29 \%$ and $156 \%$ higher than any value attained utilizing an industrial waste product. This study also confirmed that the greater strength could be identical to a higher tobermorite phase and that the recycled AAC surface showed a finer crystalline morphology.
\end{abstract}

Keywords: lightweight concrete; autoclaved aerated concrete (AAC); physical properties; mechanical properties; recycled AAC

\section{Introduction}

Malaysia's largest electricity consumers are the commercial and residential sectors, which accounted for approximately $49.5 \%$ of the total electricity consumption in 2018 [1]. Space cooling is the feature that consumes the most energy in the commercial sector and the second most energy in the residential sector. In addition, according to a survey reported by the Japan Refrigeration and Air Conditioning Industry Association in 2017, the average annual growth in demand for air conditioners in Malaysia and Thailand from 2011 to 2016 was about 3\% and 11\%, respectively [2]. These figures indicate that cooling demand is increasing, so reducing the cooling loads would reduce the total electricity demand.

It is common to reduce the cooling loads by installing insulation layers on walls and roofs. However, wall insulation is less significant in reducing cooling loads in the Malaysian climate, particularly for commercial buildings, which are air conditioned during the day [3]. Buildings with insulated walls will be able to reduce the peak cooling loads in the middle of the day. However, insulation layers may also have adverse effects, in which heat is trapped in the room when the air conditioning system is switched off in the evening. This heat needs to be removed the following day, which creates a high energy demand for space 
cooling. Meanwhile, in buildings without an insulation layer, the indoor temperature is higher than the outdoor night temperature, so the heat from the room will be conducted outwards through the wall.

Therefore, autoclaved aerated concrete (AAC) blocks with low thermal conductivity and high heat resistance can serve simultaneously as the building's wall and insulation (without an additional insulation layer). This may be one solution to reduce the cooling peak without trapping heat inside the building. These advantages mean that AAC applications in the construction industry are growing, which increases the amount of waste [4]. This could be reduced by recycling AAC waste; however, recycling it into useful products remains a challenge for various reasons. One way to recycle AAC wastes is to use them as a raw material to produce a new form of AAC.

This paper presents the physical and mechanical properties of a newly developed AAC that utilizes recycled AAC (referred to as AAC-R) waste powder to replace the fine sand. The weight ratios of the AAC-R powder to the overall AAC-R and fine sand content were varied to optimize the composition. According to previous research, the substitution of AAC-R waste powder for fine sand would increase the crystalline tobermorite phase of AAC, which would contribute to the enhancement of its mechanical properties [5]. The results from all the samples are provided in this paper, including their microstructure, mechanical characteristics, and physical properties. Compressive strength, water absorption, density, humidity, and flexural strength tests were conducted. These tests were designed to determine if AAC was compatible with commercial AAC and ASTM C1555-03a, the Standard Practice for Autoclaved Aerated Concrete Masonry [6]. This study aimed to evaluate whether this new formulated AAC, which utilized AAC-R powder as a replacement for fine sand and could meet the standard for AAC, allowing it to be used in the construction industry. Meanwhile, this study makes a significant contribution to conserving the environment because recycling AAC waste would reduce landfilling. It would also help to reduce sand mining by partially replacing the fine sand content in AAC manufacturing.

\section{AAC Application in Malaysia}

$\mathrm{AAC}$ is a lightweight concrete with an approximate porosity of $80 \%$. It has lower shrinkage and lower thermal conductivity than traditional concrete, and the construction procedure is easier and faster [7]. The raw materials for producing AAC are silica or quartz sand, lime, cement, and aluminum powder. Silica sand has the highest composition percentage, with a weight ratio of up to 60-70\% [8]. In the manufacturing process, the fine sand needs to be ground in a ball mill to become powder. This step is one of the most energy-intensive processes in AAC manufacturing. Depending on the roughness of the raw sand, it can take up to $10 \mathrm{~h}$ [9]. In terms of energy demand, manufacturing of concrete and bricks, which are classified as non-metallic mineral products, is the second-largest consumer of industrial energy in Malaysia, accounting for $21 \%$ of total energy consumption in the industrial sector [10]. Apart from the energy demand, sourcing sand is also a significant factor that results in high material costs. According to the Malaysia Competition Commission (MyCC) report [11], from 2008 to 2015, Malaysia was a net importer of sand (except in 2013). Hence, reducing sand consumption in construction is part of a sustainable approach to resource management.

The economic sector in Malaysia is growing continuously, leading to national development. Based on a 2016 report, the country's GDP increased by $4.2 \%$ in the first quarter (Q1) [12]. This growth indirectly reflected the external growth in construction. The GDP from construction increased in the first quarter of 2016 to MYR 12,558 million, up from MYR 11,992 million in the fourth quarter of 2015 [13]. In the construction field, AAC applications are becoming popular and are increasingly being used as building materials in Malaysia and Thailand. Many AAC production facilities have been established since 1996 [14]. AAC wastes are also produced during the manufacturing process at construction sites, whereby cracked end products will be rejected. As a result, plenty of AAC wastes become available during construction. Moreover, Construction and Demolition (C\&D) waste is often 
regarded as the major solid waste contributor to landfill, and about $40 \%$ of this waste is concrete [15]. With about $40 \%$ of solid wastes being construction wastes [16], recycling of concrete wastes is an excellent way to reduce the amount of material in landfills.

\section{Recycling AAC}

Many AAC studies have utilized different wastes to replace the sand content or silicabased material in AAC production. For example, expanded perlite waste (EPW) was used to substitute ground quartz sand, and the results showed that adding EPW could reduce thermal conductivity [17]. However, increasing the weight percentage reduces thermal conductivity even more, and only compositions with up to $10 \%$ can maintain compressive strength. Similarly, substitutions such as iron tailing [18] and desulfurization slag [19] also negatively affected the compressive strength when these substitutions were increased to more than $15 \%$ by weight. Other researchers used municipal solid waste incineration bottom ash (IBA) to replace silica flour/fly ash. The uniform pore structure and smaller pore size of IBAAACs enhanced the compressive strength for a given density, compared to the use of conventional AAC. However, no thermal conductivity results were reported [20]. Meanwhile, glassy waste was used to replace a small proportion of sand, with the results showing that this could produce a similar compressive strength to the reference AAC sample [21]. Thongtha et al. also developed AAC by replacing sand and lime with waste sugar sediment to investigate three essential features of concrete that could improve its weight, compressive strength, and thermal resistance. It was discovered that as the weight was reduced, the compressive strength increased considerably, resulting in adequate resistance that could be used as building blocks without the need for an insulation layer [22].

On the other hand, research using AAC-R waste powder to replace the fine sand content in raw materials has been conducted on AAC in floor applications and other applications [23]. However, this process has not been undertaken for building walls, and the percentage of AAC-R used has not been reported to enhance its mechanical properties [9,24]. With AAC wastes available in abundance from production plants and construction sites, this would reduce the production costs of using fine sand. Reducing construction wastes by recycling AAC wastes to produce a new form of AAC product is an economical method and would reduce the volume of waste sent for landfilling; thus, the negative impacts on the environment would be reduced.

Changes in the sand composition will change the porosity of the AAC. This will affect the density, compressive strength, and thermal conductivity, and hence the heat gain between the building wall and the environment. This study prepared AAC samples using different weight ratios of AAC-R waste powder to replace the fine sand content. The investigation focused on mechanical properties in order to examine the developed AAC's effectiveness when used in building blocks. In addition, other mechanical properties such as the flexural strength, density, and water absorption of the samples were discussed and compared to commercial AACs in terms of how they might reduce cooling loads in hot and humid climate conditions.

\section{Methodology for AAC-R Substitution}

\subsection{AAC Production and Preparation of Raw Materials}

The materials used in AAC manufacturing are lime $(\mathrm{CaO})$, Portland cement, aluminum $(\mathrm{Al})$, anhydrite $\left(\mathrm{CaSO}_{4}\right)$, and fine sand, all of which are commercially and readily available. Lime ( $17.167 \%$ by weight), Portland cement ( $17.870 \%$ by weight), aluminum $(0.094 \%$ by weight), anhydrite (2.352\% by weight), and fine sand are comprised in the AAC mixture (62.517\% by weight).

In this study, the investigation was undertaken with various combinations of fine sand and AAC-R. The fine sand content was substituted with AAC-R at $0 \%, 15 \%, 20 \%$, $25 \%, 30 \%, 35 \%, 40 \%, 45 \%$, and $50 \%$ by weight, while the content of the other raw materials was fixed at the values stated in Table 1 . The ingredients were combined with water 
in a $20 \mathrm{~cm} \times 20 \mathrm{~cm} \times 100 \mathrm{~cm}$ mold for these compositions, as shown in Figure 1a,b. The preparation process was performed by combining fine sand and AAC-R, cement, lime, water, and an expansion agent (aluminum powder) and pouring the mixture into a mold. The pouring and mixing cycle took about $5.5 \mathrm{~min}$. Generally, in the manufacturing process, after being added to the concrete, the aluminum powder reacts with the silica, resulting in the formation of millions of microscopic hydrogen bubbles [24]. The hydrogen subsequently evaporates, leaving highly closed-cell aerated concrete. The final product was aerated concrete, which was cut into blocks before being steam- and pressure-cured in an autoclave. All the samples underwent the autoclaving process at a pressure of 12 bars and at a temperature of 180-190 degrees Celsius for $8 \mathrm{~h}$.

Table 1. Content of raw materials in AAC, showing the variations between the fine wet sand and the recycling powder (AAC-R).

\begin{tabular}{|c|c|c|c|c|c|c|c|c|c|}
\hline \multirow[t]{2}{*}{ Raw Materials } & & & \multicolumn{7}{|c|}{ Content of Raw Materials (Weight\%) } \\
\hline & AAC-R0 & AAC-R15 & AAC-R20 & AAC-R25 & AAC-R30 & AAC-R35 & AAC-R40 & AAC-R45 & AAC-R50 \\
\hline Lime & \multicolumn{9}{|c|}{ Held constant at 17.167} \\
\hline Cement & \multicolumn{9}{|c|}{ Held constant at 17.870} \\
\hline Anhydride & \multirow{2}{*}{\multicolumn{9}{|c|}{$\begin{array}{l}\text { Held constant at } 2.352 \\
\text { Held constant at } 0.094\end{array}$}} \\
\hline Aluminum & & & & & & & & & \\
\hline Fine sand & 62.517 & 53.139 & 50.014 & 46.888 & 43.762 & 40.636 & 37.510 & 34.384 & 31.259 \\
\hline AAC-R & 0.000 & 9.378 & 12.503 & 15.629 & 18.755 & 21.881 & 25.007 & 28.133 & 31.259 \\
\hline
\end{tabular}

Note: Recycled AAC is presented as AAC-R with the respective composition percentage used to replace the fine sand. For example, if the newly developed AAC-R consists of 30\% recycled content, it will be called AAC-R30, which means $30 \%$ AAC-R and $70 \%$ fine sand.

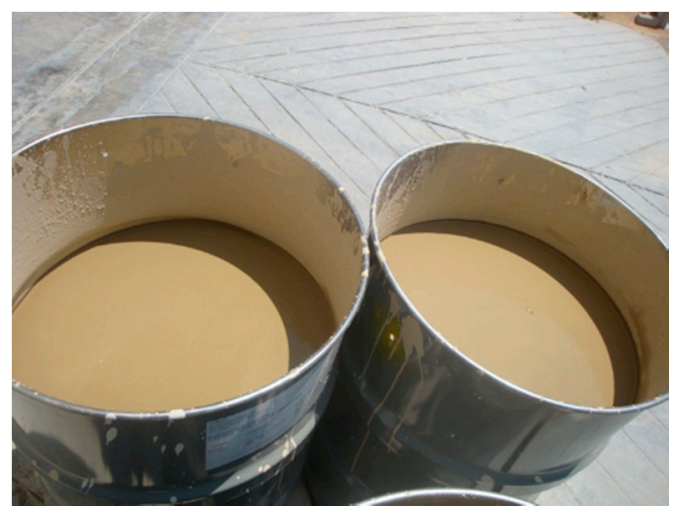

(a)

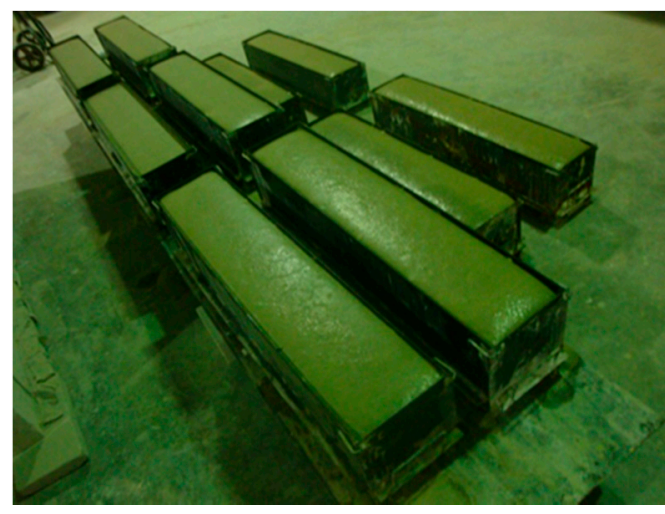

(b)

Figure 1. Mixture of AAC (a) and mixture of AAC in the mold for the autoclaving process (b).

\subsection{Mechanical and Physical Measurement}

After undergoing the autoclaving process in the autoclaving machine, the samples were evaluated for compressive strength and flexural strength, following the ASTM C155503a standard. All the newly generated AAC-R samples were cut to a minimum size of $7.5 \mathrm{~cm} \times 7.5 \mathrm{~cm} \times 7.5 \mathrm{~cm}$ before the mechanical tests were undertaken, as shown in Figure 2a-f. For density and water absorption testing, the samples were dried at $105^{\circ} \mathrm{C}$ for $24 \mathrm{~h}$ and then tested following the ASTM C642-97 standard. The microstructure of the AAC composition, which was mixed with other compositions, was photographed using FE scanning electron microscopy (FESEM). The formation and character of the tobermorite phase were determined using X-ray diffraction (XRD). 


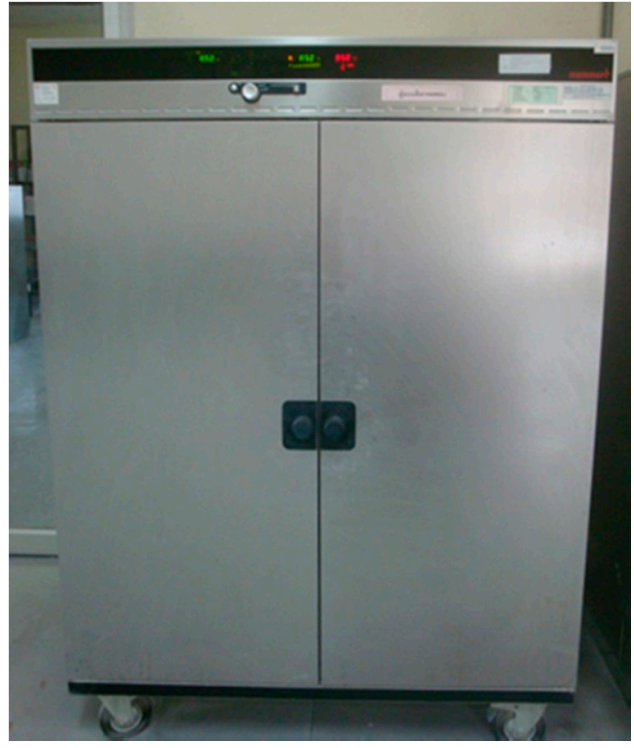

(a)

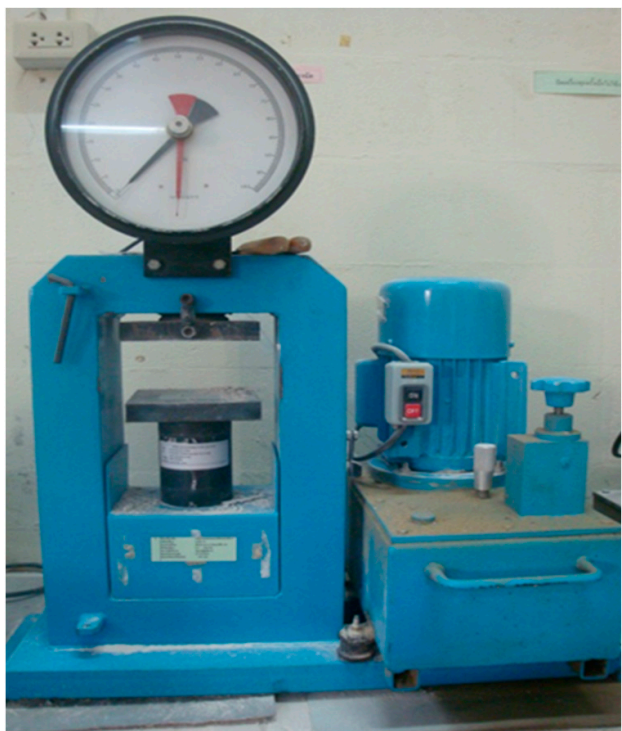

(c)

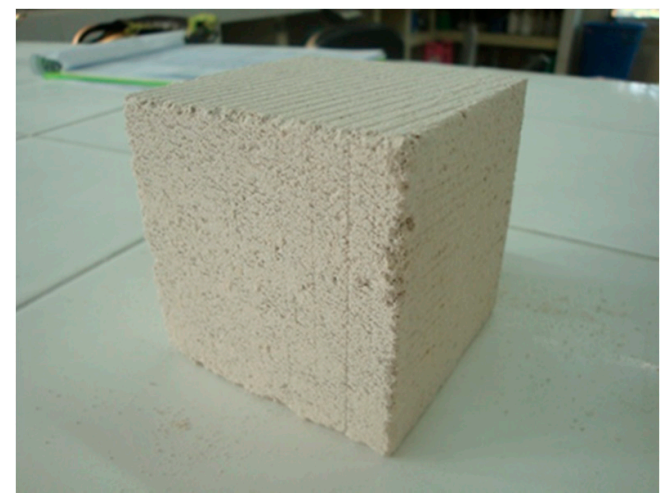

(e)

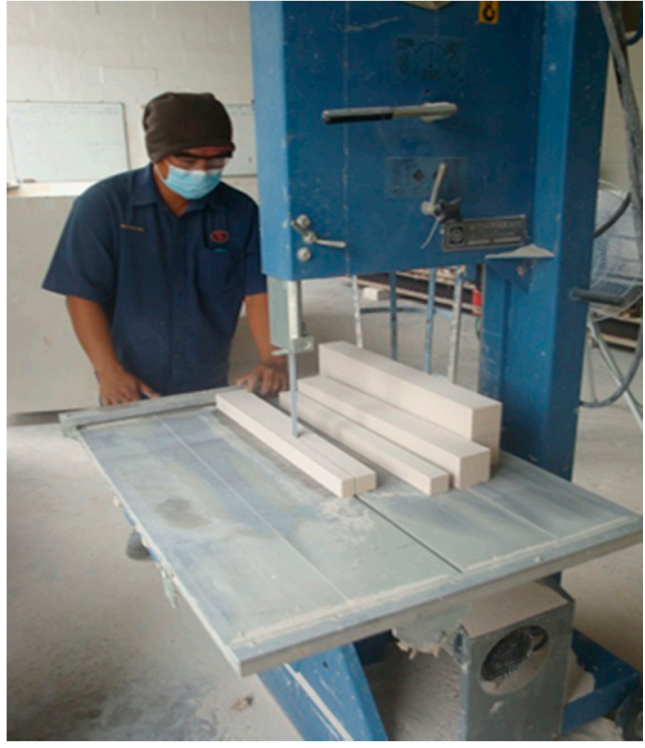

(b)

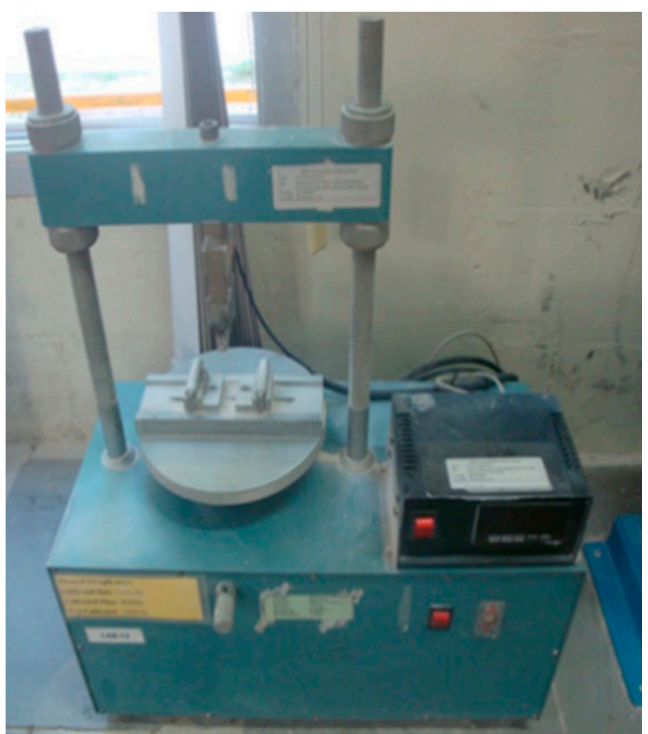

(d)

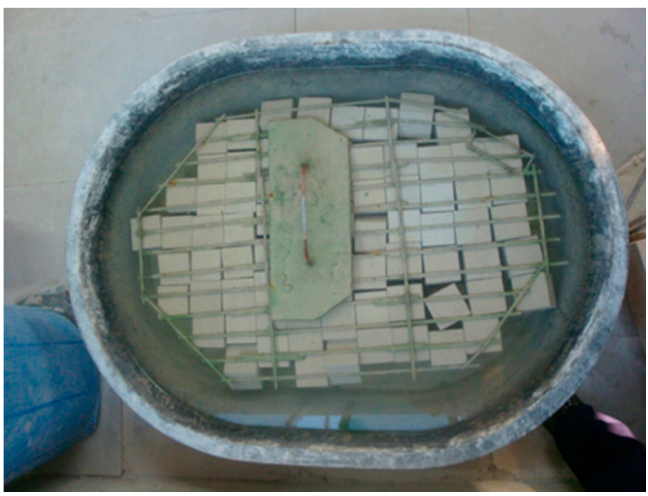

(f)

Figure 2. Hot air oven (a), cutting the AAC for the mechanical and physical test (b), compressive strength testing machine (c), flexural strength testing machine (d), size of concrete for compressive strength testing (e), concrete for absorption testing (f). 


\section{Discussion of Results}

\subsection{Compressive and Flexural Strength}

Figure 3 depicts the compressive strength of the AAC compositions with various amounts of fine AAC-R wastes. The AAC-R30 sample had the highest compressive strength of $5.85 \mathrm{~N} / \mathrm{mm}^{2}$. This value was higher than those of the other forms of lightweight concrete, which contained copper tailings and blast furnace slag $\left(4.00 \mathrm{~N} / \mathrm{mm}^{2}\right)$ [25], coal bottom ash $\left(2.78 \mathrm{~N} / \mathrm{mm}^{2}\right)[26]$, and high-calcium fly ash and natural zeolite $\left(4.51 \mathrm{~N} / \mathrm{mm}^{2}\right)$ [27]. The value for the recycled waste AAC-R30 was higher than the value found in previous studies due to the presence of more crystalline tobermorite in this composition [7]. As indicated in Figure 3, the compressive strength of the commercial autoclaved aerated concrete was around $5.04 \mathrm{~N} / \mathrm{mm}^{2}$, while that of the ASTM C1692-18 is $5.00 \mathrm{~N} / \mathrm{mm}^{2}$, as shown by the red line [6].

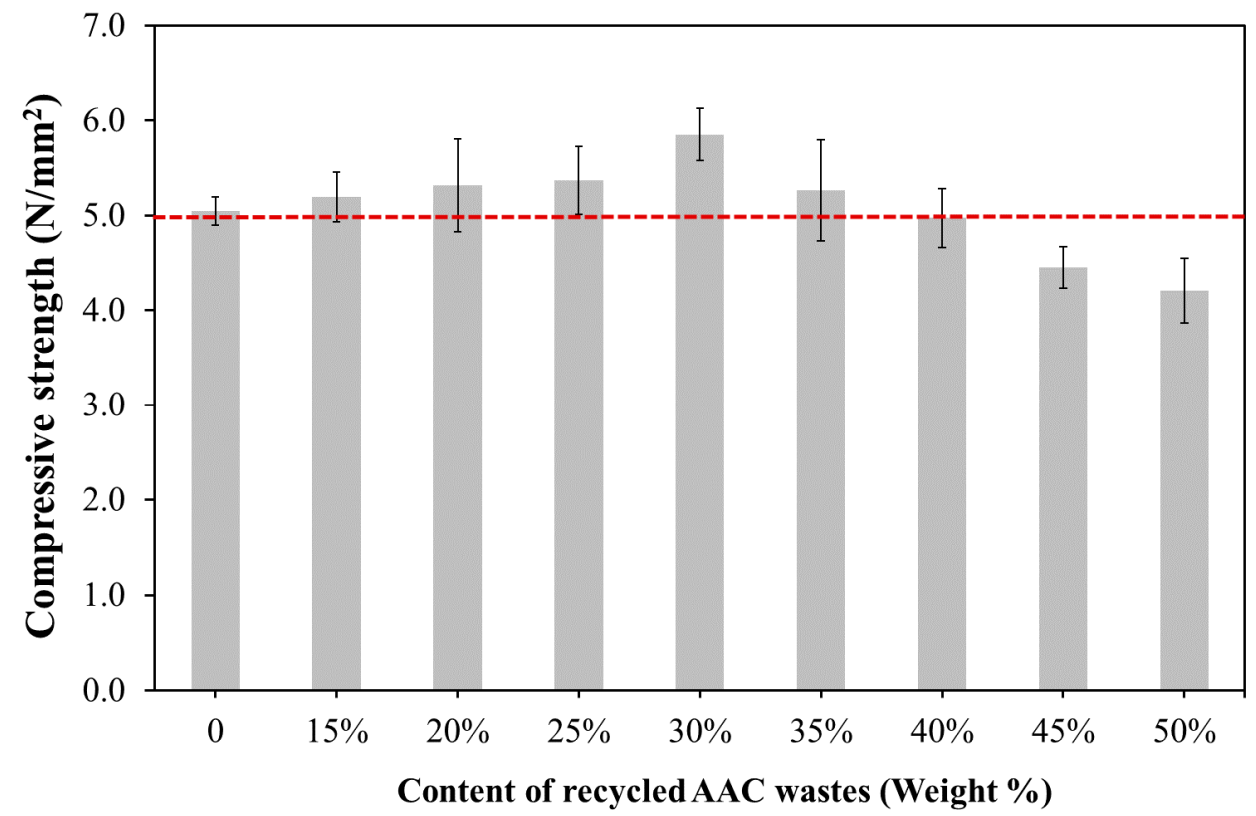

Figure 3. Compressive strength of AAC with different content of fine AAC-R wastes (the red dash line indicates the minimum acceptable value of compressive strength according to ASTM C1692-18).

The compressive strength of the AAC-R30 was roughly 16\% higher than that of commercial AAC. It was between 29\% and 156\% higher than any figure recorded in earlier research using industrial waste in AAC mixtures. This increment clearly shows that replacing sand with AAC-R30 results in AAC with great compressive strength. The substitution of AAC-R30 for fine sand increased the crystalline tobermorite phase, whereby this phase could enhance both the mechanical and thermal properties of the AAC [28]. Furthermore, the ideal compositions in each procedure that resulted in the highest compressive strength complied with ASTM C 1555-03a. These findings clearly show that AAC-R could be utilized as an alternative raw material in the manufacturing of AAC. Despite its lower compressive strength, recycled AAC is also a lighter concrete. AAC weighs up to $78 \%$ less than traditional concrete [29]. Although the lighter AAC does not fit all and every structure, its light weight would not be a deterrent to using it in many construction situations. It is more cost-effective and allows for speedier construction. This material is indisputably a construction material suitable for a variety of constructions circumstances, being both economically advantageous and entirely sufficient in strength to be used in the correct circumstances.

Meanwhile, as shown in Figure 4, flexural strength peaked with the AAC-R35 sample and then dropped with the AAC-R20 sample. All the samples met the minimum flexural strength requirement of at least $30 \%$ of compressive strength, around $1.77 \mathrm{~N} / \mathrm{mm}^{2}$. Additionally, this outstanding performance means that walls containing AAC-R30 could display improved displacement capacity and reduce the damage caused by horizontal actions. The 
higher compressive strength could improve the cracking resistance and provide a higher capacity to resist horizontal action and displacement [30,31].

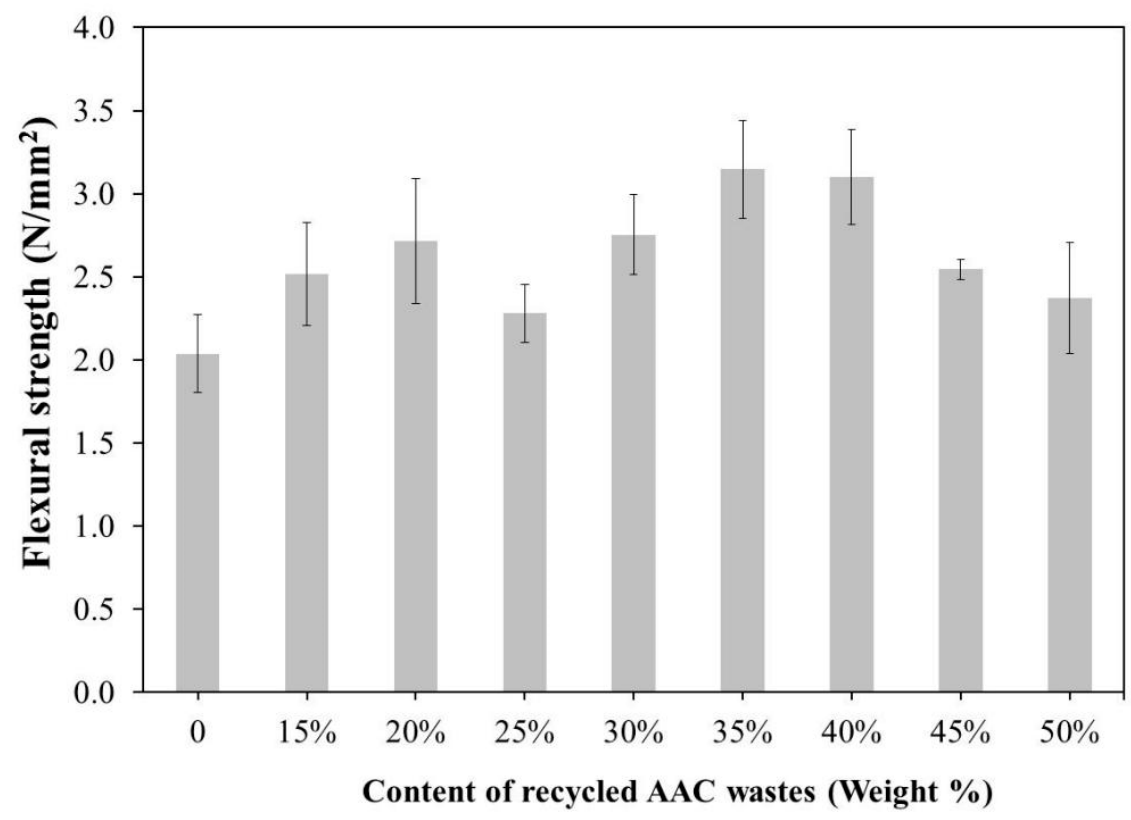

Figure 4. Flexural strength of AAC with different content of fine AAC-R wastes.

\subsection{Density and Humidity}

While lowering the manufacturing costs, the partial substitution with waste materials improves the properties of AAC [32-36]. The microstructure and density of the AAC represent its physical properties, and the density of AAC determines most of its attributes, including its compressive strength, thermal performance, and drying shrinkage.

The density of AAC typically ranges between 0.30 and $1.8 \mathrm{~g} / \mathrm{cm}^{3}$ [29]. The density of the new AAC blocks ranged from 0.53 to $0.61 \mathrm{~g} / \mathrm{cm}^{3}$. AAC humidity was also explored to determine the AAC density values. Figures 5 and 6 show that the higher the density (from the AAC-R20, AAC-R25, and AAC-R30 samples), the lower the humidity, which is excellent and could prevent mold growth in such building materials. Furthermore, the materials produced by the autoclaved method could weigh between $15 \%$ and $25 \%$ more than the materials produced by dry ovens [37]. Additionally, a more prolonged autoclaved treatment $(>8 \mathrm{~h}$ ) could improve the density by contributing to the development of additional hydration [38].

As shown in Figure 5, AAC has a minimum density of $0.50 \mathrm{~g} / \mathrm{cm}^{3}$ and a maximum density of $0.80 \mathrm{~g} / \mathrm{cm}^{3}$. When the AAC-R component was doubled, the density remained relatively steady. When the AAC-R component was between $0 \%$ and $50 \%$ by weight, the density was between $0.53 \mathrm{~g} / \mathrm{cm}^{3}$ and $0.62 \mathrm{~g} / \mathrm{cm}^{3}$. A higher volume of Autoclaved Aerated Concrete corresponded to a lower density. As shown by the red line, the minimum and maximum requirements of the ASTM Standard were $0.5 \mathrm{~g} / \mathrm{cm}^{3}$ and $0.8 \mathrm{~g} / \mathrm{cm}^{3}$, respectively. All the samples met the ASTM Standard's minimum density criterion for AAC.

Figure 6 depicts the humidity as the AAC-R content varied. The humidity of the autoclaved aerated concrete showed an inconsistent trend, ranging between $20.3 \%$ and $32.7 \%$ when the recycling powder concentration was between $0 \%$ and $50 \%$ by weight. The humidity values of all the samples were within the acceptable range, which is less than $50 \%$, as outlined by the ASTM C642-97 [6]. The inconsistency of the humidity content might be caused by the porosity of the cement matrix [39]. 


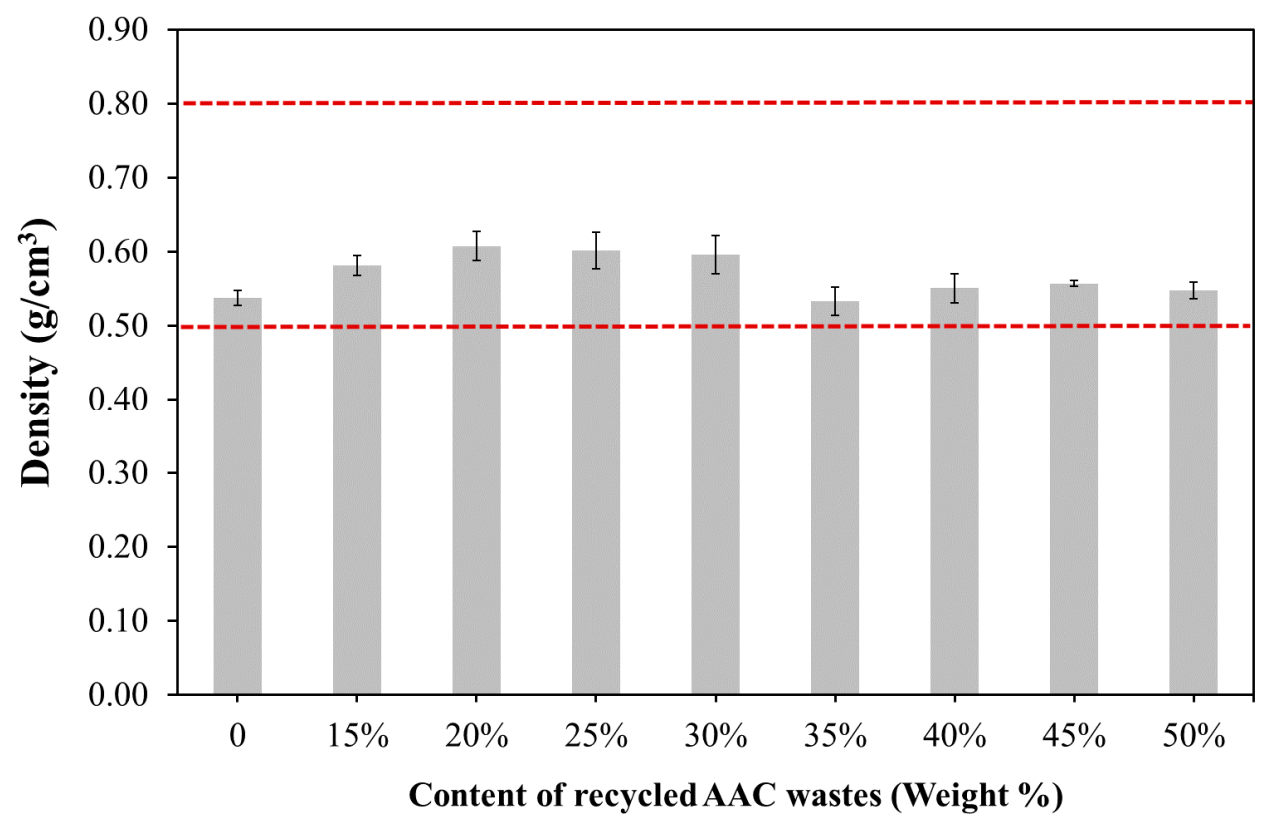

Figure 5. The density of AAC with varied fine recycling powder content (the upper and lower red dash lines indicate the acceptable range of density according to the ASTM C1692-18).

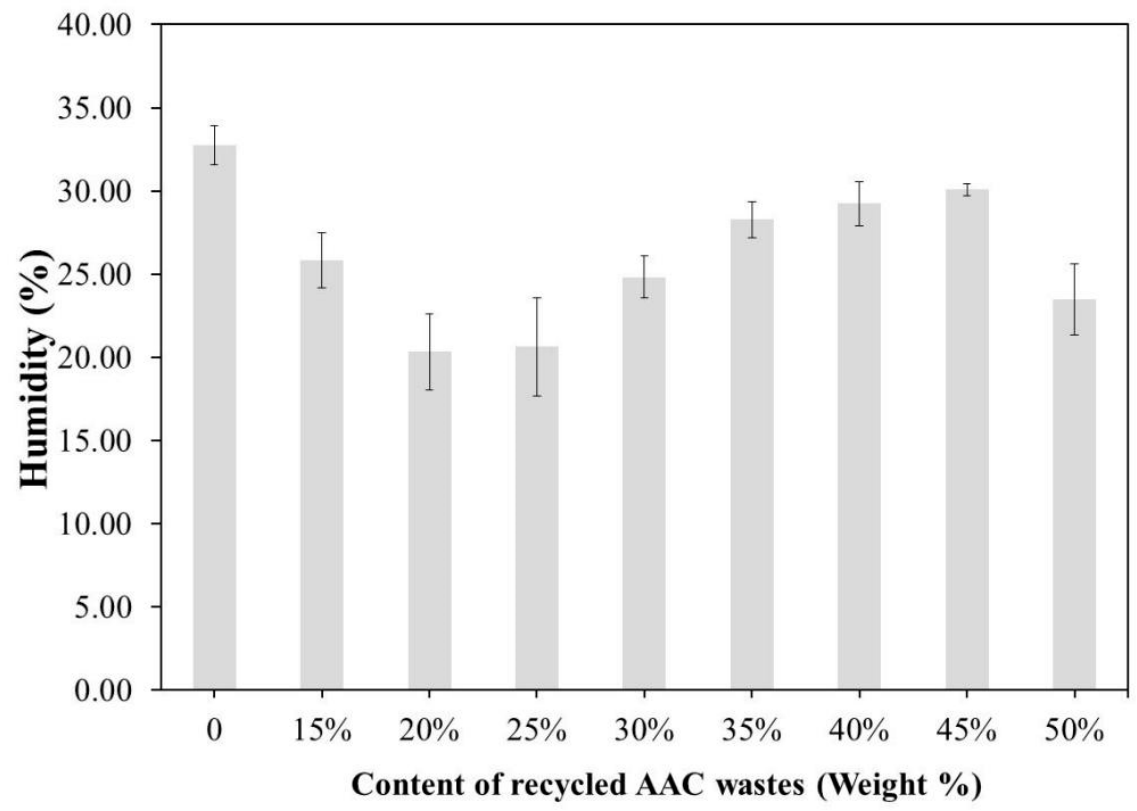

Figure 6. The humidity of AAC with varied fine recycle powder content.

\subsection{Water Absorption}

AAC absorbs a large volume of water because of its high porosity and large drainage channel [38]. Water absorption is divided into two routes, one through the capillary hole (pore diameter $1 \mathrm{~m}$ ) and the other through the many ventilation ports. Although all the matrix's capillaries are saturated with water, the ventilation apertures generate twisting routes for extending water absorption [40]. Even as the recycling powder content increased, the water absorption of AAC-R remained steady. The water absorption range was between $0.38-0.47 \mathrm{~g} / \mathrm{cm}^{3}$ when the recycling powder concentration was between $0 \%$ and $50 \%$ by weight, as illustrated in Figure 7. This means that the water absorption tendency and density were identical. In this study, the maximum water absorption of the AAC was around $0.45 \mathrm{~g} / \mathrm{cm}^{3}$ at a $50 \%$ recycling powder concentration. Water was absorbed at a rate 
of less than $0.5 \mathrm{~g} / \mathrm{cm}^{3}$, as per the ASTM Standard requirements, as shown by the red line. The 50\% samples had the most extensive water absorption, implying that the higher the recycled content in the AAC, the higher the water absorption. However, the compressive strength would be lower.

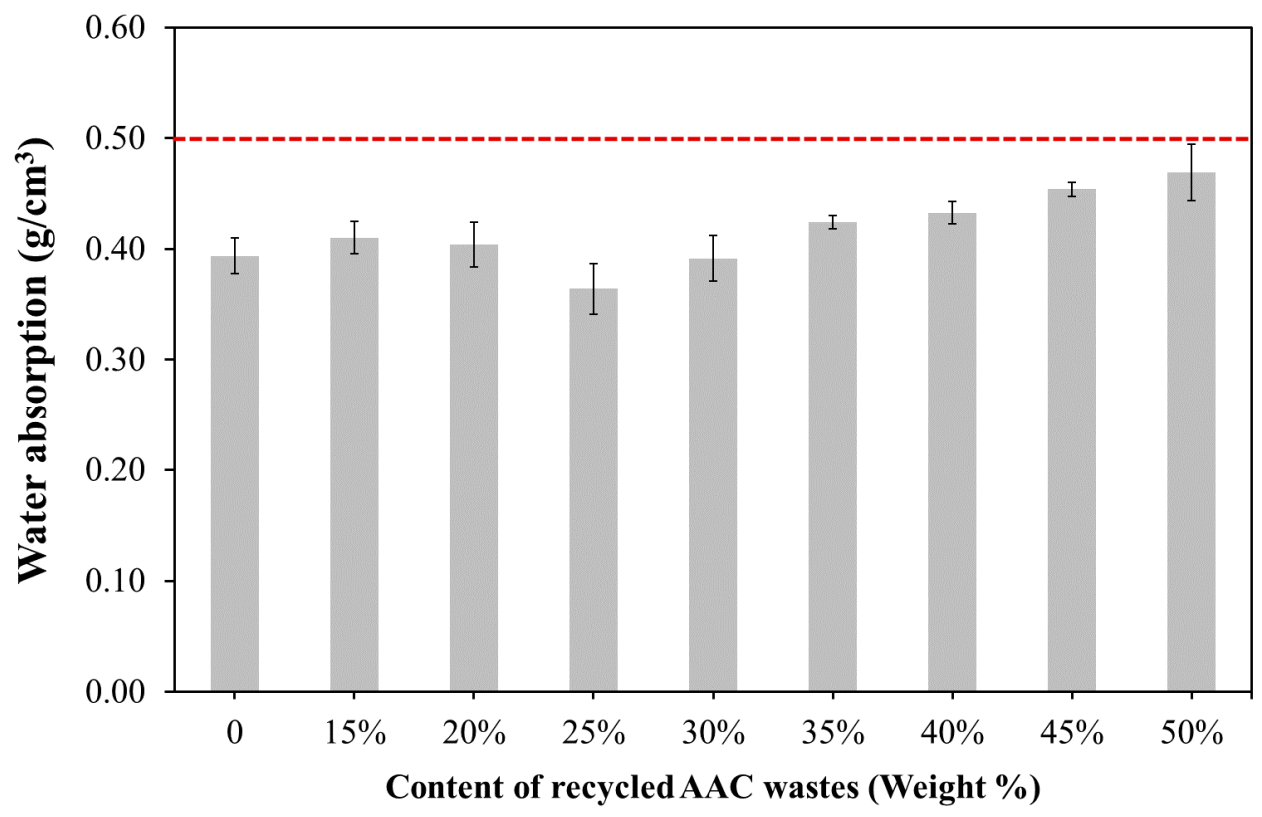

Figure 7. AAC water absorption ratios with varied concentrations of fine recycled powder (the red dash line indicates the maximum acceptable value of water absorption according to the ASTM C1692-18 standard).

\subsection{AAC Microstructure}

Replacing the sand content with AAC-R waste powder improves the crystalline tobermorite content and increases the AAC's strength. The tobermorite phase formation and quality were discovered and analyzed using FE scanning electron microscopy (FESEM). $\mathrm{X}$-ray diffraction (XRD) tests were performed on the AAC microstructure composition and mixes of different compositions. According to a literature review, previous studies by Narayanan et al. and Kus et al. only indicated that the tobermorite structure in AAC affects the compressive strength $[29,41,42]$. Cong et al. also showed that the increased crystallinity of the tobermorite phases in the AAC samples improved the compressive strength [31].

However, previous research has not established the consequences of increasing the tobermorite phase proportion, as attained by Autoclaved Aerated Concrete [7,25-27,32,43-45]. To investigate and demonstrate that increasing the proportion of tobermorite crystals increases the compressive strength of Autoclaved Aerated Concrete, the ideal composition for each process was analyzed, and the phase development in each AAC mixture was compared. This was accomplished using $X$-ray diffraction (XRD). Figure 8 depicts the $\mathrm{X}$-ray diffraction patterns of the AAC-R30, AAC-R50, and traditional AAC. All the samples contained calcite, quartz, and tobermorite phases, while AAC-R30 showed less calcite phase, which was nearly uncountable. The phase ratios in each sample were determined using Equations (1)-(3), which are well-known formulae and frequently used in conjunction with the fabrication of complex structure materials. The intensities of the highest calcite, quartz, and tobermorite peaks were referred to as Icalcite, Iquartz, and Itobermorite, respectively.

$$
\begin{aligned}
& \% \text { ratio of the calcite phase }=\frac{\text { Icalcite }}{(\text { Iquartz }+ \text { Itobermorite }+ \text { Icalcite })} \times 100 \\
& \% \text { ratio of the quartz phase }=\frac{\text { Iquartz }}{(\text { Iquartz }+ \text { Itobermorite }+ \text { Icalcite })} \times 100
\end{aligned}
$$




$$
\% \text { ratio of the tobermorite phase }=\frac{\text { Itobermorite }}{(\text { Iquart } z+\text { Itobermorite }+ \text { Icalcite })} \times 100
$$

In the AAC-R30, AAC-R50, and traditional AAC samples, the calcite, quartz, and tobermorite phase ratios were calculated, and these are listed in Table 2. Table 2 shows that a higher proportion of tobermorite and calcite phases and a smaller proportion of quartz phases corresponded to higher compressive strength. The AAC-R30 samples showed the highest ratios of tobermorite phases, with values of roughly $71.3 \%$ and $28.7 \%$ of quartz phases. This illustrated the phase ratio changes in the AAC that occurred when the usual raw material, sand, was replaced with AAC-R waste powder. This finding supports the idea that increasing the tobermorite phase improves the mechanical properties of AAC. Importantly, this outcome agrees strongly with earlier research $[7,43]$.

Table 2. Ratios of recycled AAC phase formation.

\begin{tabular}{cccc}
\hline Composition & \multicolumn{3}{c}{ Ratios of Phase Formation (\%) } \\
\hline & Calcite & Quartz & Tobermorite \\
\hline Traditional AAC & 24.1 & 47.5 & 28.4 \\
AAC-R30 & 0 & 28.7 & 71.3 \\
AAC-R50 & 7.5 & 42.8 & 35.6 \\
\hline
\end{tabular}

XRD analysis also validated the crystal structure of the samples. Figure 8 displays the XRD patterns formed when comparing the AAC-R30, AAC-R50, and traditional AAC samples, showing that the AAC-R50 samples were mostly calcite and quartz, with little tobermorite. Meanwhile, the AAC-R30 samples were classified as crystalline due to the tobermorite and quartz, while traditional AAC consisted of all phases but had less tobermorite phase than AAC-R30. The presence of tobermorite phase in AAC is crucial as it suggests many promising exceptional features. The findings of this experiment show that the newly developed AAC-R30 can control the generation of microporosity in the cement matrix while also accelerating the phase transformation of calcite to tobermorite. Microscopic analysis verified the presence of a crystalline tobermorite phase in AAC, enhancing its mechanical characteristics. Samples with higher levels of tobermorite phase contributed to the mechanical parameters of the AAC, such as compressive strength, as shown in Table 2.

Figure 9a-c depict the morphology of the AAC-R30, AAC-R50, and traditional AAC surfaces to show the microstructure of each composition by FESEM examination. The surface of the AAC-R30 blocks showed finer pores with more thick pores than the AAC-R50 block, which contains more large pores. In contrast, AAC-R30 also had a smoother surface with significantly fewer pores than traditional AAC. 


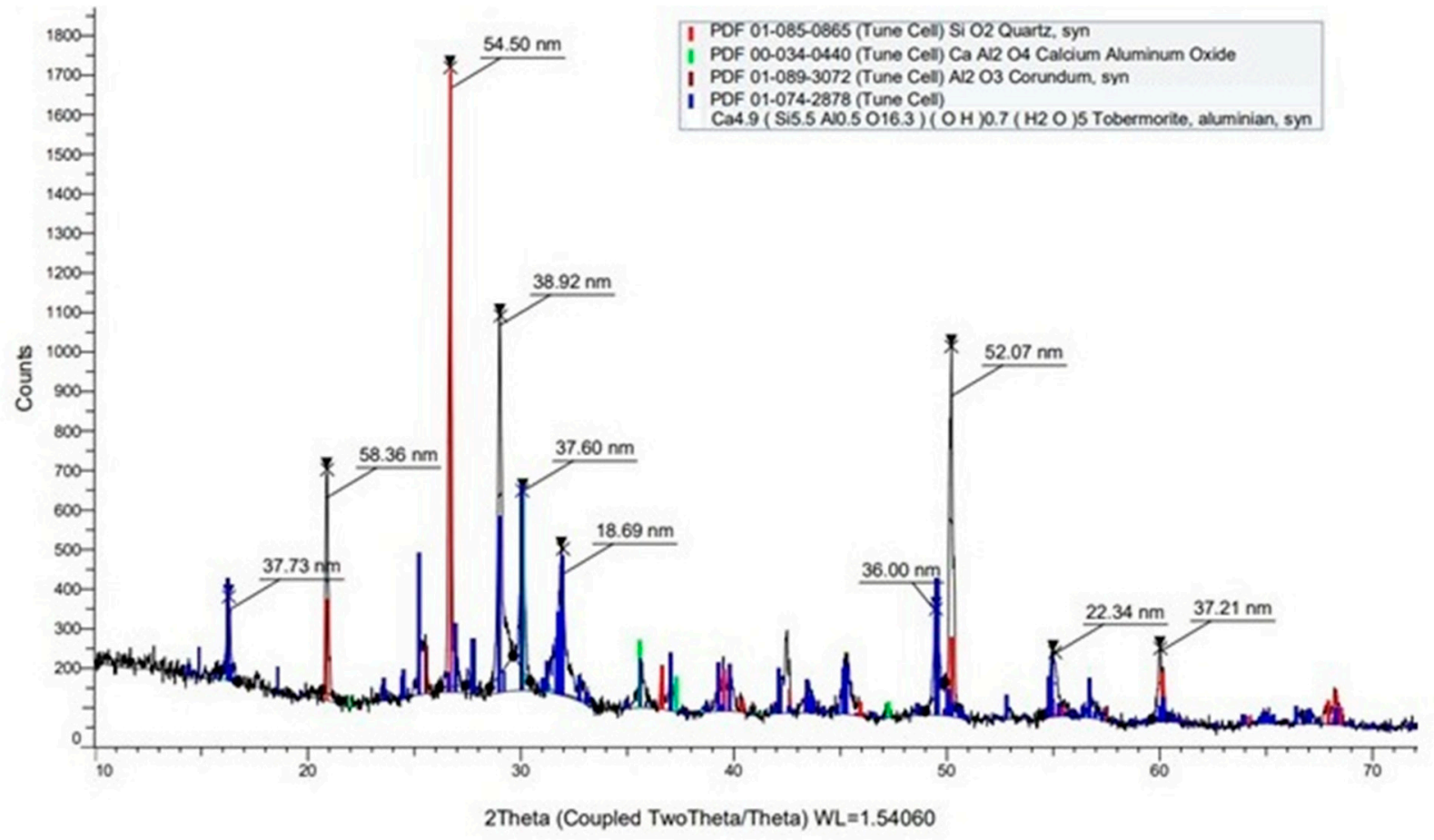

(a)

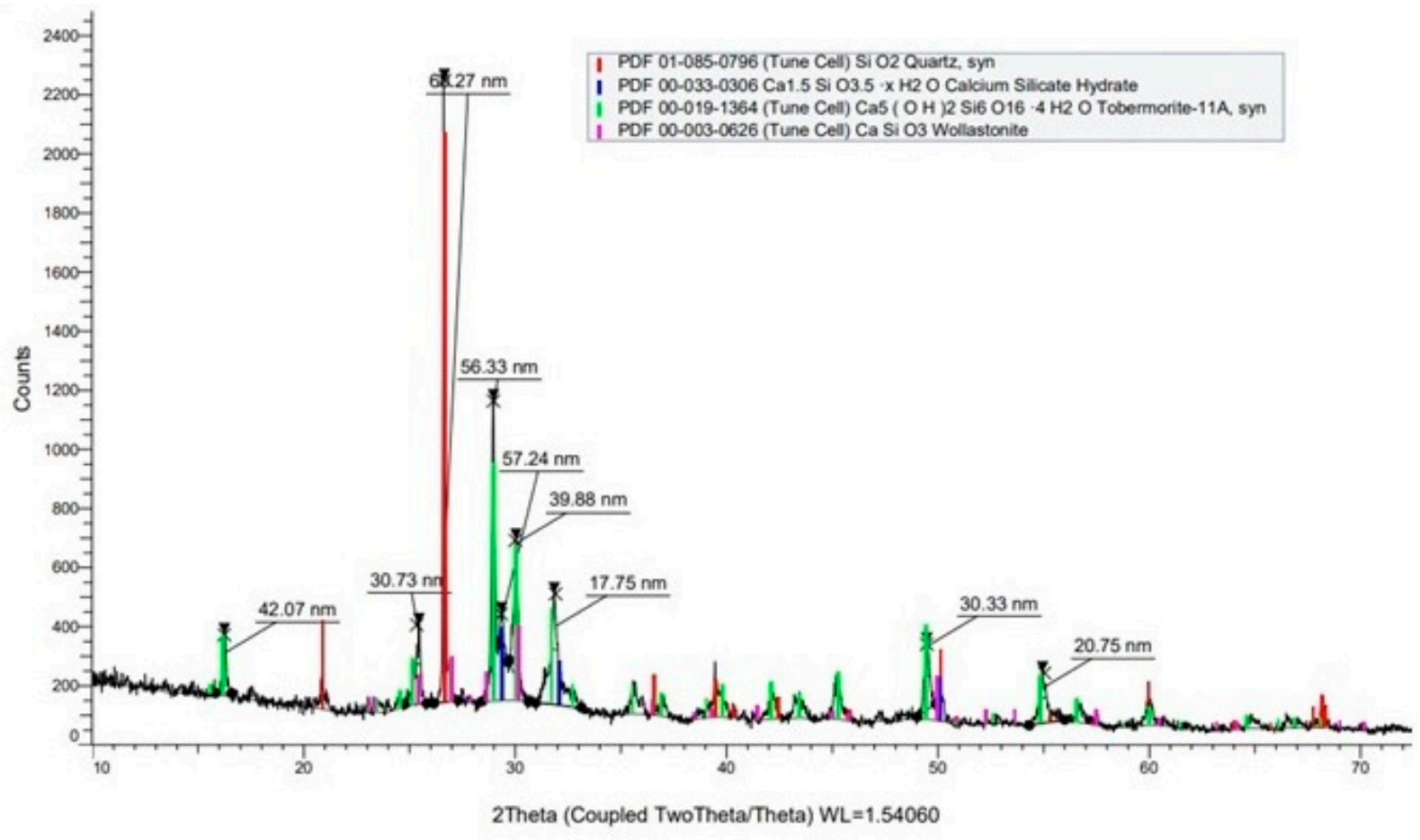

(b)

Figure 8. Cont. 


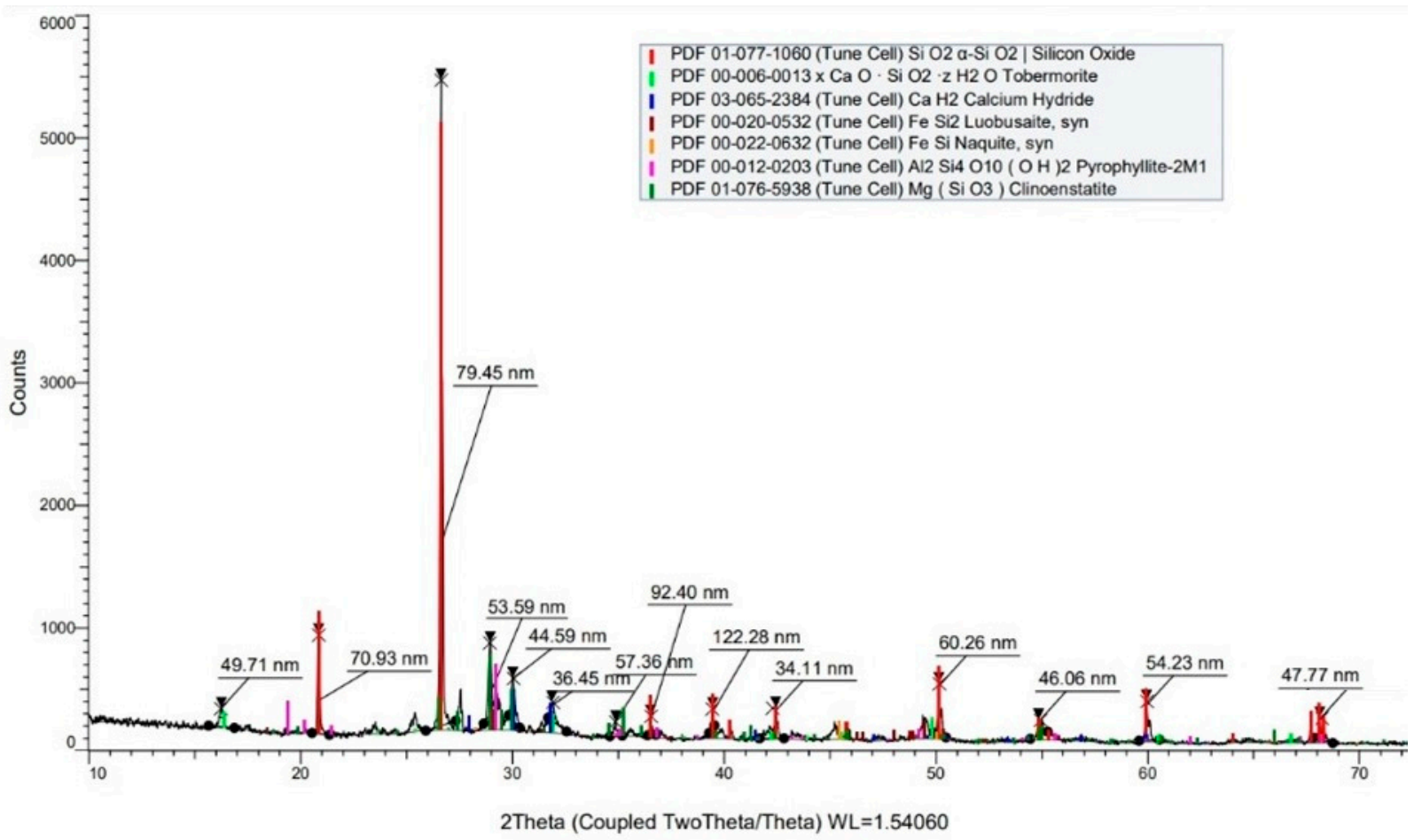

(c)

Figure 8. XRD patterns of AAC-R30 (a), AAC-R50 (b), and traditional AAC (c).

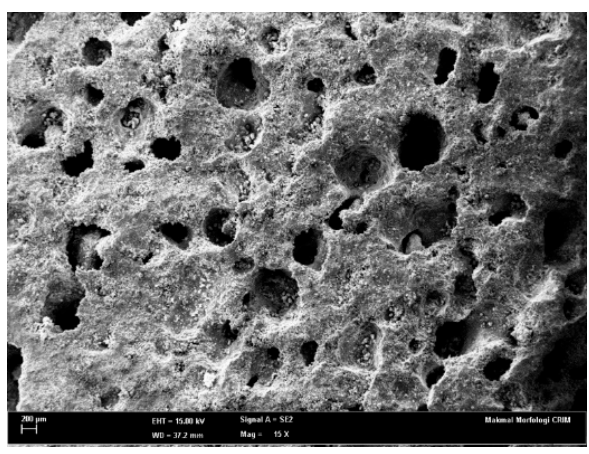

(a)

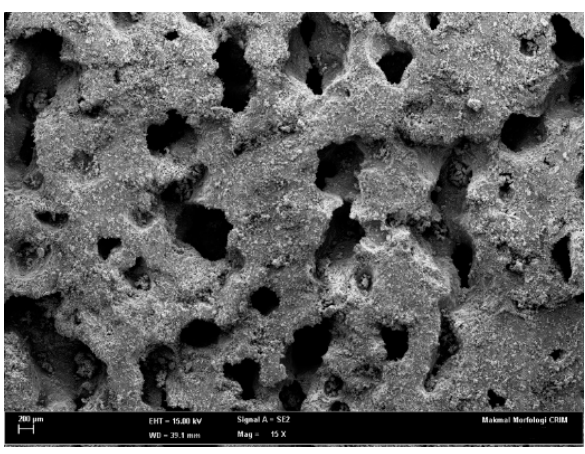

(b)

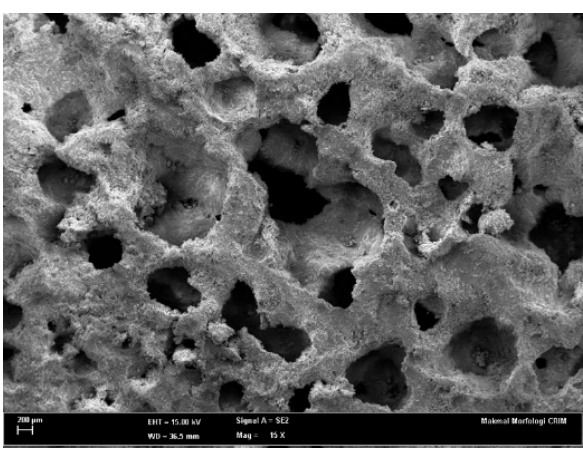

(c)

Figure 9. FESEM micrographs of AAC-R30 (a), AAC-R50 (b), and traditional AAC (c) at $200 \mu \mathrm{m}$.

Figure 9 shows that no cracks appeared on any samples, indicating greater mechanical strength and smoother and more refined surfaces. Greatly enlarged FESEM micrographs were also produced 5000 times for further investigation into the crystallinity of all the samples. The AAC sample crystallization image resulting from the characterization of FESEM with increased crystallization is shown in Figure 10a-c. Tobermorite crystals were found in every AAC sample. Based on the crystalline structure, AAC-R30 (Figure 10a) had more crystal than traditional AAC (Figure 10c), while AAC-R50 (Figure 10b) had finer pores. As a result, AAC had a lower specific density due to the many smaller porosities inside the matrix of microscopic particles. 


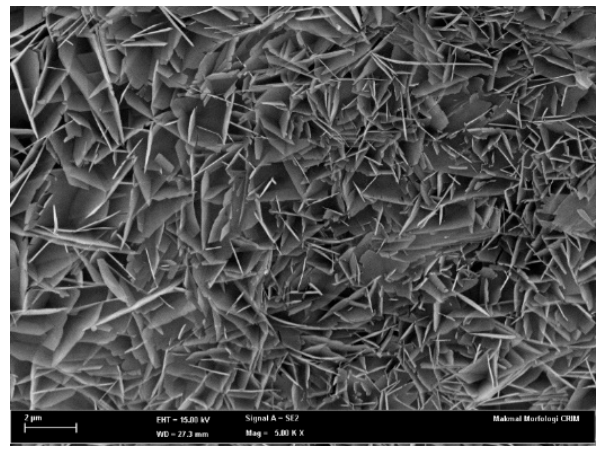

(a)

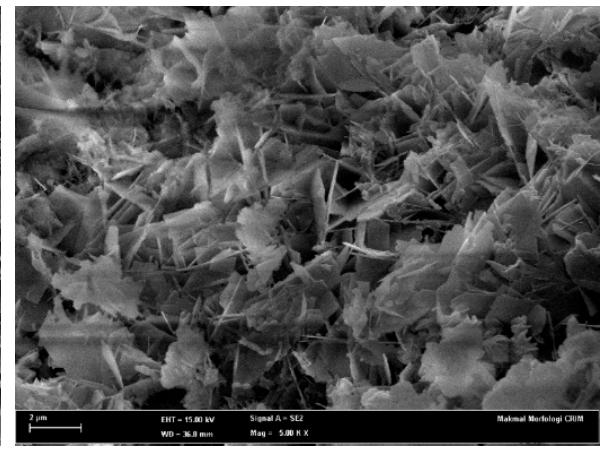

(b)

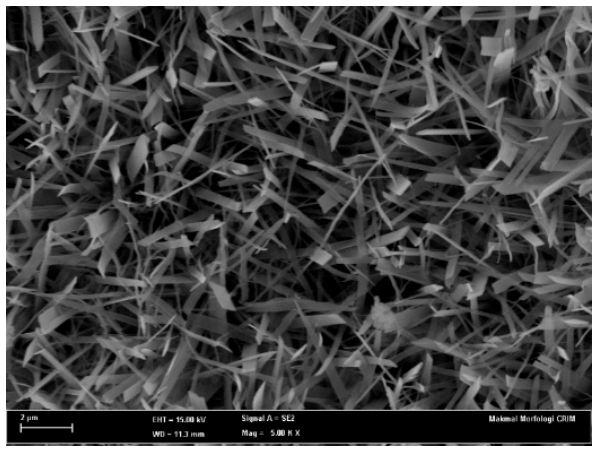

(c)

Figure 10. Comparison of the crystalline structure of specimens at $2 \mu \mathrm{m}$ for (a) AAC-R30, (b) AACR50, and (c) traditional AAC.

The microstructure of AAC-R30 could be distinguished by its more refined needle-like crystalline structures and porous combination shape. The sub-micron needle crystals of AAC-R30 overlapped, forming a solid skeleton and obliterating the spaces between the layers, as opposed to AAC-R50, which contained less needle-like characteristics. This indicates that the samples' microstructures possessed high compressive strength. Thin tobermorite platelets made up the visible particle matrix. The platelets had a consistent thickness of a few tens of nanometers or less and a width of 5 to 10 microns. Tobermorite crystals appear intermingled in the pore structure, generating a sharp-angled corner cell network [46].

\section{Ecological and Economic Benefits}

The use of AAC-R can be regarded as necessary for three main reasons. First, it is an industrial waste product; second, it is available in significant quantities; and third, it currently involves substantial environmental and economic costs when it is not used, as it is disposed of in landfill sites. Applying recycled AAC-R in Autoclaved Aerated Concrete fabrication could become an alternative method of disposing of AAC-R waste, which could bring about simultaneous environmental benefits. It could become a more widely used alternative raw material in the future. Furthermore, the substitution of AAC-R could also reduce operational costs. Based on a previous study by Thongtha et al., replacing fine sand with waste sugar sediment could reduce operational costs by up to $36 \%$ [22]. As AAC-R is also categorized as a waste material, this study could also contribute to reducing the fabrication costs and the environmental effects.

\section{Conclusions}

To summarize the current research, replacing sand content with AAC-R waste powder increased the strength of the newly developed Autoclaved Aerated Concrete. The optimal composition (AAC-R30) demonstrated the highest compressive strength $\left(5.85 \mathrm{~N} / \mathrm{mm}^{2}\right)$ and the highest proportion of tobermorite phase $(71.3 \%)$, both of which were significantly higher than the values identified in the other AAC mixes tested, which contained a variety of industrial by-products. Depending on the comparison mix, the compressive strength was between $29 \%$ and $156 \%$ higher. In the future, AAC with the optimal AAC-R composition could be considered an alternative material to traditional concrete for use in non-structural (non-load bearing) walls and masonry. Because AAC-R is a by-product with a notable negative environmental effect, using it in such large amounts could also reduce the environmental and human impacts of waste disposal. We therefore recommend that these new recycled AAC block samples be commercialized. Depending on the findings of further studies, this newly developed AAC may be used as a concrete wall-building material. 
Author Contributions: Conceptualization, A.R.R. and A.F.; methodology and investigation, A.R.R., A.F. and A.T.; writing-original draft preparation A.R.R.; writing-review and editing, A.R.R., A.F. and M.S.N.; visualization and supervision, A.F., N.A. and A.T.; project administration, A.F.; funding acquisition, A.F. All authors have read and agreed to the published version of the manuscript.

Funding: This research was funded by the Ministry of Education (FRGS/1/2018/TK06/UKM/02/1).

Institutional Review Board Statement: Not applicable.

Informed Consent Statement: Not applicable.

Acknowledgments: The authors would like to thank the Ministry of Education (FRGS/1/2018/ TK06/UKM/02/1) for funding this project and our collaborative partners Naresuan University and the INSEE Superblock Co., Ltd., Thailand, for their many forms of assistance.

Conflicts of Interest: The authors declare no conflict of interest. The funders had no role in the design of the study; in the collection, analyses, or interpretation of data; in the writing of the manuscript; or in the decision to publish the results.

\section{References}

1. Malaysia Energy Information Hub. National Energy Balance 2018; Energy Commision: Putrajaya, Malaysia, 2019. Available online: https:/ / meih.st.gov.my/documents/10620/f2f4c39b-4748-4c5d-b90a-fc36ba880264 (accessed on 6 January 2021).

2. The Japan Refrigeration and Air Conditioning Industry Association. World Air Conditioner Demand by Region; The Japan Refrigeration and Air Conditioning Industry Association: Tokyo, Japan, 2019.

3. Tang, C.; Chin, N. Building Energy Efficiency Technical Guideline for Passive; BSEEP: Kuala Lumpur, Malaysia, 2017. Available online: http:/ /bseep.gov.my/publications/ (accessed on 27 December 2021).

4. Rahman, R.A.; Fazlizan, A.; Asim, N.; Thongtha, A. A review on the utilization of waste material for autoclaved aerated concrete productiont. J. Renew. Mater. 2021, 9, 61-72. [CrossRef]

5. Thongtha, A.; Maneewan, S.; Punlek, C.; Ungkoon, Y. Application using sugar sediment to enhance mechanical properties of autoclaved aerated concrete. Appl. Mech. Mater. 2013, 459, 664-668. [CrossRef]

6. $\quad$ ASTM International. ASTM C1692-18 Standard Practice for Construction and Testing of Autoclaved Aerated Concrete (AAC) Masonry; ASTM International: Philadelphia, PA, USA, 2018.

7. Ungkoon, Y.; Sittipunt, C.; Namprakai, P.; Jetipattaranat, W.; Kim, K.-S.; Charinpanitkul, T. Analysis of microstructure and properties of autoclaved aerated concrete wall construction materials. J. Ind. Eng. Chem. 2007, 13, 1103-1108.

8. Hamad, A.J. Materials, Production, Properties and Application of Aerated Lightweight Concrete: Review. Int. J. Mater. Sci. Eng. 2014, 2, 152-157. [CrossRef]

9. Lam, N.N. Recycling of Aac Waste in the Manufacture of Autoclaved Aerated Concrete in Vietnam. Int. J. GEOMATE 2021, 20, 128-134. [CrossRef]

10. Malaysia Energy Information Hub. National Energy Balance 2016; Energy Commission: Putrajaya, Malaysia, 2017. Available online: https:/ / meih.st.gov.my/documents/10620/9a9314a1-cf11-4640-a9de-3b31f336a416 (accessed on 27 December 2021).

11. Malaysia Competition Commission (MyCC). Market Review of Building Materials in the Construction Industry under Competition Act 2010; Malaysia Competition Commision: Kuala Lumpur, Malaysia, 2017. Available online: https:/ /www.mycc.gov.my/marketreview / final-report-market-review-of-building-materials-in-the-construction-industry (accessed on 6 January 2022).

12. Macrotrends. Malaysia GDP Growth Rate. Available online: https://www.macrotrends.net/countries/MYS/malaysia/gdpgrowth-rate (accessed on 20 December 2021).

13. Malaysia Government Debt to GDP | 2021 Data | 2022 Forecast | 1970-2020 Historical. Available online: https: / tradingeconomics. $\mathrm{com} /$ malaysia/government-debt-to-gdp (accessed on 20 December 2021).

14. Chin Hin's AAC Manufacturing Its Rising Star I The Edge Markets. Available online: https:/ /www.theedgemarkets.com/article/ chin-hin $\backslash \mathrm{T} 1 \backslash$ textquoterights-aac-manufacturing-its-rising-star (accessed on 20 December 2021).

15. Osman, W.; Mohd Nawi, M.; Saad, R.; Osman, N.; Abdul Rahim, M. Implementation of resource recovery practices among Malaysian construction stakeholders. Geogr. Malays. J. Soc. Space 2016, 12, 95-101.

16. Eusuf, M.A.; Ibrahim, M.; Islam, R. The Construction and Demolition Wastes in Klang Valley, Malaysia. J. Malays. Inst. Plan. 2012, 10, 99-124.

17. Różycka, A.; Pichór, W. Effect of perlite waste addition on the properties of autoclaved aerated concrete. Constr. Build. Mater. 2016, 120, 65-71. [CrossRef]

18. Cai, L.; Ma, B.; Li, X.; Lv, Y.; Liu, Z.; Jian, S. Mechanical and hydration characteristics of autoclaved aerated concrete (AAC) containing iron-tailings: Effect of content and fineness. Constr. Build. Mater. 2016, 128, 361-372. [CrossRef]

19. Chen, Y.L.; Ko, M.S.; Chang, J.E.; Lin, C.T. Recycling of desulfurization slag for the production of autoclaved aerated concrete. Constr. Build. Mater. 2018, 158, 132-140. [CrossRef]

20. Song, Y.; Li, B.; Yang, E.H.; Liu, Y.; Ding, T. Feasibility study on utilization of municipal solid waste incineration bottom ash as aerating agent for the production of autoclaved aerated concrete. Cem. Concr. Compos. 2015, 56, 51-58. [CrossRef] 
21. Walczak, P.; Małolepszy, J.; Reben, M.; Szymański, P.; Rzepa, K. Utilization of Waste Glass in Autoclaved Aerated Concrete. Procedia Eng. 2015, 122, 302-309. [CrossRef]

22. Thongtha, A.; Maneewan, S.; Punlek, C.; Ungkoon, Y. Investigation of the compressive strength, time lags and decrement factors of AAC-lightweight concrete containing sugar sediment waste. Energy Build. 2014, 84, 516-525. [CrossRef]

23. Bergmans, J.; Nielsen, P.; Snellings, R.; Broos, K. Recycling of autoclaved aerated concrete in floor screeds: Sulfate leaching reduction by ettringite formation. Constr. Build. Mater. 2016, 111, 9-14. [CrossRef]

24. Ullrich, A.; Garbev, K.; Bergfeldt, B. In Situ X-ray Diffraction at High Temperatures: Formation of $\mathrm{Ca}_{2} \mathrm{Sio}_{4}$ and Ternesite in Recycled Autoclaved Aerated Concrete. Minerals 2021, 11, 789. [CrossRef]

25. Huang, X.Y.; Ni, W.; Cui, W.H.; Wang, Z.J.; Zhu, L.P. Preparation of autoclaved aerated concrete using copper tailings and blast furnace slag. Constr. Build. Mater. 2012, 27, 1-5. [CrossRef]

26. Kurama, H.; Topçu, I.B.; Karakurt, C. Properties of the autoclaved aerated concrete produced from coal bottom ash. J. Mater. Process. Technol. 2009, 209, 767-773. [CrossRef]

27. Jitchaiyaphum, K.; Sinsiri, T.; Jaturapitakkul, C.; Chindaprasirt, P. Cellular lightweight concrete containing high-calcium fly ash and natural zeolite. Int. J. Miner. Metall. Mater. 2013, 20, 462-471. [CrossRef]

28. Rahman, Z.A.; Lee, J.Y.Y.; Rahim, S.A.; Lihan, T.; Idris, W.M.R. Application of gypsum and fly ash as additives in stabilization of tropical peat soil. J. Appl. Sci. 2015, 15, 1006-1012. [CrossRef]

29. Narayanan, N.; Ramamurthy, K. Structure and properties of aerated concrete: A review. Cem. Concr. Compos. 2000, 22, 321-329. [CrossRef]

30. Cai, L.; Tang, T.; Liu, M.; Xie, D. Comparative study of carbide slag autoclaved aerated concrete (AAC) manufactured under thermal oven and microwave pre-curing process: Foaming course, rough body strength and physic-mechanical properties. Constr. Build. Mater. 2020, 236, 117550. [CrossRef]

31. Bayat, A.; Liaghat, G.H.; Ghalami-Choobar, M.; Ashkezari, G.D.; Sabouri, H. Analytical modeling of the high-velocity impact of autoclaved aerated concrete (AAC) blocks and some experimental results. Int. J. Mech. Sci. 2019, 159, 315-324. [CrossRef]

32. Wang, Q.; Chen, Y.; Li, F.; Sun, T.; Xu, B. Microstructure and properties of silty siliceous crushed stone-lime aerated concrete. J. Wuhan Univ. Technol. Mater. Sci. Ed. 2006, 21, 17-20. [CrossRef]

33. Cong, X.Y.; Lu, S.; Yao, Y.; Wang, Z. Fabrication and characterization of self-ignition coal gangue autoclaved aerated concrete. Mater. Des. 2016, 97, 155-162. [CrossRef]

34. Mostafa, N.Y.; El-Hemaly SA, S.; Al-Wakeel, E.I.; El-Korashy, S.A.; Brown, P.W. Activity of silica fume and dealuminated kaolin at different temperatures. Cem. Concr. Res. 2001, 31, 905-911. [CrossRef]

35. Liu, Y.; Chen, G.; Wang, Z.; Chen, Z.; Gao, Y.; Li, F. On the seismic performance of autoclaved aerated concrete self-insulation block walls. Materials 2020, 13, 2942. [CrossRef]

36. Rafiza, A.R.; Chan, H.Y.; Thongtha, A.; Jettipattaranat, W.; Lim, K.L. An Innovative Autoclaved Aerated Concrete (AAC) with Recycled AAC Powder for Low Carbon Construction. IOP Conf. Ser. Earth Environ. Sci. 2019, 268. [CrossRef]

37. Wongkeo, W.; Thongsanitgarn, P.; Pimraksa, K.; Chaipanich, A. Compressive strength, flexural strength and thermal conductivity of autoclaved concrete block made using bottom ash as cement replacement materials. Mater. Des. 2012, 35, 434-439. [CrossRef]

38. Jerman, M.; Keppert, M.; Výborný, J.; Černý, R. Hygric, thermal and durability properties of autoclaved aerated concrete. Constr Build. Mater. 2013, 41, 352-359. [CrossRef]

39. Hojati, M.; Rajabipour, F.; Radlińska, A. Drying shrinkage of alkali-activated cements: Effect of humidity and curing temperature. Mater. Struct. 2019, 52. [CrossRef]

40. Goual, M.S.; Bali, A.; de Barquin, F.; Dheilly, R.M.; Quéneudec, M. Isothermal moisture properties of Clayey Cellular Concretes elaborated from clayey waste, cement and aluminium powder. Cem. Concr. Res. 2006, 36, 1768-1776. [CrossRef]

41. Narayanan, N.; Ramamurthy, K. Microstructural investigations on aerated concrete. Cem. Concr. Res. 2000, 30, 457-464. [CrossRef]

42. Kus, H.; Carlsson, T. Microstructural investigations of naturally and artificially weathered autoclaved aerated concrete. Cem. Concr. Res. 2003, 33, 1423-1432. [CrossRef]

43. Yang, R.; Zhu, J.; Wu, Z.; Wu, Z.; Li, M.; Peng, C. Thermal insulation and strength of autoclaved light concrete. J. Wuhan Univ. Technol. Mater. Sci. Ed. 2011, 26, 132-136. [CrossRef]

44. Cabrillac, R.; Fiorio, B.; Beaucour, A.L.; Dumontet, H.; Ortola, S. Experimental study of the mechanical anisotropy of aerated concretes and of the adjustment parameters of the introduced porosity. Constr. Build. Mater. 2006, 20, 286-295. [CrossRef]

45. Koronthalyova, O. Moisture storage capacity and microstructure of ceramic brick and autoclaved aerated concrete. Constr. Build. Mater. 2011, 25, 879-885. [CrossRef]

46. Mostafa, N.Y. Influence of air-cooled slag on physicochemical properties of autoclaved aerated concrete. Cem. Concr. Res. 2005, 35, 1349-1357. [CrossRef] 